\title{
Plasma-Assisted Silver Deposition on Titanium Surface: Biocompatibility and Bactericidal Effect
}

\author{
Eliziane da Rocha Camargo ${ }^{a}$, Kayam Zardo Hamdar ${ }^{a}$, Maria Luiza Ferreira dos Santos ${ }^{b}$
}

\author{
Guilherme Burgel , Carolina Camargo de Oliveira $^{b}$ (D), Vanessa Kava ${ }^{\text {, Rodrigo Perito Cardoso }}{ }^{d}$ (D),
}

\author{
Cláudia Eliana Bruno Marino ${ }^{a "}$
}

\author{
${ }^{a}$ Universidade Federal do Paraná, Departamento de Engenharia Mecânica, Curitiba, PR, Brasil \\ ${ }^{b}$ Universidade Federal do Paraná, Departamento de Biologia Celular, Curitiba, PR, Brasil \\ ${ }^{c}$ Universidade Federal do Paraná, Departamento de Genética, Curitiba, PR, Brasil \\ ${ }^{d}$ Universidade Federal de Santa Catarina, Departamento de Engenharia Mecânica, Florianópolis, SC, \\ Brasil
}

Received: December 13, 2020; Revised: January 25, 2021; Accepted: February 21, 2021

Dental implants are especially susceptible to bacterial adhesion and so microbial contamination. Several techniques have been explored in order to obtain implant surfaces enriched with silver (Ag). The main challenge is to obtain a bactericidal effect keeping the surface biocompatible. In this regard plasma-assisted deposition is a very attractive technique due to its versatility and low environmental impact. Thus, the present work aimed at evaluating the chemical stability, antibacterial activity, and biocompatibility of a commercially pure titanium (cp-Ti) surface containing very low amounts of plasmadeposited Ag. Ag deposition obtained by 10 minutes sputtering was able to promote antibacterial action (around 30\%) on a clearly cytocompatible Ti/Ag surface with no apparent impact on biocompatibility. Taken together these results indicate that the proposed deposition process has a great potential for dental implant application with the advantage of using very small amounts of silver to achieve efficacy.

Keywords: silver plasma deposition, bactericidal effect, biocompatibility.

\section{Introduction}

Titanium implants are widely used clinically, but infections remain one of the most serious complications and a real challenge for professionals of this area. It can require removal of the implant and repeated surgery. The incidence of infections associated with implants and treatment limitations are mainly related to adherent bacteria biofilm formation on the implant surface. Biofilms generate bacteria highly resistant to host immunological defense and also to antimicrobial therapies ${ }^{1}$. In addition, antibiotic therapy when repeatedly applied can lead to antibiotics resistant bacteria development, limiting their activity spectrum, resulting in serious limitation to control certain infections ${ }^{2}$. In recent years, the persistence of antibacterial effects of inorganic over organic agents has attracted considerable attention and interest of researchers ${ }^{3,4}$.

Metallic nanoparticles antibacterial, antiviral, and antifungal efficacies, due to their high surface/volume ratio and high capacity to release metal ions, have been widely studied. Some metal ions can interact with intracellular components of bacteria leading to its death. Silver (Ag) has been recognized as one of the most effective metals for application as antimicrobial agent ${ }^{5}$. Moreover, silver nanoparticles are nowadays one of the most studied inorganic agents ${ }^{6}$. The antimicrobial activity of silver nanoparticles is not entirely understood, but some effects are

*e-mail: claudiamarino@ufpr.br already known. Nanoparticles adhere to the bacteria surface and, in contact with either the cell wall or membrane, alter its properties and functions (Figure 1). In addition, silver ions are released by silver nanoparticles dissolution and can interact with thiol-containing proteins, enhancing those effects ${ }^{7,8}$. When in the cytosol, Ag ions chemical affinity to biochemical agents that play vital functions in bacteria account to its antibacterial mechanisms. These ions bind to enzymes responsible for energy conversion and metabolic activity, leading to cell death. Moreover, silver can disrupt DNA inhibiting its replication and consequently impairing cell division?.

Several studies have been carried out on surface modification with inorganic agents to cease infections ${ }^{10}$. The antibacterial activity of silver ions, from nanoparticles, and their mechanisms of action have been demonstrated in Gram-positive (Staphylococcus aureus) and Gram-negative (Escherichia coli) strains ${ }^{2,11,12}$. It was proved that an adequate concentration of Ag can decrease adherence and bacterial colonization on titanium implant surface, without causing side effects to health cells, such as osteoblasts ${ }^{10}$.

For application in implants, the great challenge is to control the right $\mathrm{Ag}$ amount to be deposited on a surface, which is at the limit of the dual function: efficient bactericidal action with low toxicity, since implants must maintain a bioactive and biocompatible surface. In addition to bactericidal action, cytocompatibility of the silver-deposited surface must be 


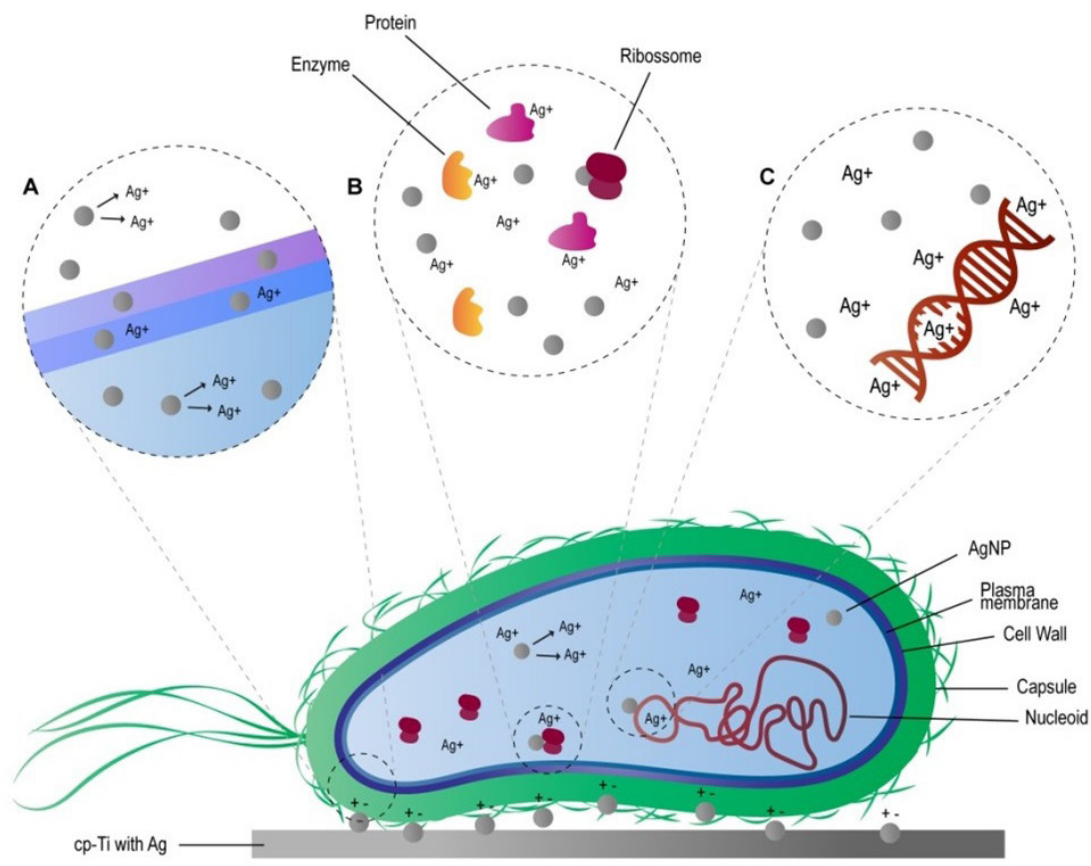

Figure 1. Hypothetical activity of silver in gram-negative bacteria (not to scale).

guaranteed, considering the existence of a possible toxic component. Therefore, it is necessary to investigate both the antibacterial action and the viability of cells grown over silver-deposited Ti surfaces. In the study by Muñoz et al. ${ }^{13}$, a value was obtained for the Minimum Inhibitory Concentration (MIC) of Ag nanoparticles in human cells of $10^{\circ}-10^{2} \mu \mathrm{g} / \mathrm{mL}$ of $\mathrm{Ag}\left(10^{-2}-10^{0} \mathrm{mmol} / \mathrm{L}\right)$. For $2.7 \mathrm{at} \% \mathrm{Ag}$, Kheur ${ }^{8}$ showed high toxicity and bactericide action. Studies with mouse fibroblasts indicated that concentration of $3.5 \times 10^{-3} \mathrm{mmol} / \mathrm{L} \mathrm{Ag}$ ions is lethal to the cells, reducing cell growth in $50 \%{ }^{14}$. Therefore, it is necessary to control the deposition parameters so that a balance between antibacterial action and compatibility with the host cell can be achieved.

Several processing techniques were explored in the scientific literature and in industrial and clinical applications in order to obtain titanium surfaces enriched with antibacterial agents $^{2,15}$. Silver nanoparticles have been studied as antibacterial agent, but research towards the development of more bio-sustainable synthesis methodologies is still needed ${ }^{6}$. The plasma-assisted deposition technique is an alternative due to its high versatility and low environmental impact. Additionally the plasma-assisted deposition technique allows low deposition rates, being possible to precisely control the $\mathrm{Ag}$ amount deposited on the implant surface. This aspect is very relevant because even though silver is an efficient bactericidal agent, the toxic effects of metal ions to the host cells must be considered.

Researches based on obtaining Ag deposition by plasmaassisted techniques have been carried out by different methods. Ag deposition obtained by plasma-based ion implantation method in hydroxyapatite ${ }^{15}$, porous titanium dioxide containing Ag nanoparticles obtained by electrolytic plasma oxidation method ${ }^{16,17}$, and by magnetron sputtering followed by micro-arc oxidation method ${ }^{18}$, are some examples.
These can give an idea of plasma techniques varieties and applications. As a general advantage of such process is the possibility of treatments at low temperature, since plasma is a very active physicochemical medium.

In this context, this research focused on depositing very low amounts of Ag on cp-Ti via pulsed DC-plasma, aiming its application on dental implants. Therefore deposited samples surfaces were morphologically and chemically characterized. Next, antibacterial activity of these surfaces was accessed by its activity against Staphylococcus aureus and Escherichia coli bacteria. Furthermore, biocompatibility of cp-Ti/Ag surface was characterized by the evaluation of murine fibroblasts adhesion and growth.

\section{Material and Methods}

\subsection{Materials}

Grade 2 titanium samples (cp-Ti: commercially pure) (Titanium do Brasil $($ ), with dimensions of $20 \mathrm{~mm}$ (length) x $10 \mathrm{~mm}$ (width) x $3 \mathrm{~mm}$ (thickness), were used. Even though polished surfaces are not suitable for all implant components, in this work, to enable a reliable characterization, polished samples were used to precisely access the effect of very low amounts of Ag deposition on the Ti surface on biocompatibility and bactericidal effect. The samples were embedded in bakelite and subsequently sanded using 200, 400, 600, and 1200 grit sandpaper, with cleaning in distilled water between steps. Then, the samples were polished with 6,3 , and $1 \mu \mathrm{m}$ diamond paste, followed by polishing with alumina suspension of 1 and $0.3 \mu \mathrm{m}$ until obtaining a mirror finishing. The polished samples were removed from bakelite support and subjected to ultrasound cleaning process with isopropyl alcohol, 70\% ethanol, and 
distilled water, in this sequence, for 10 minutes in each solution. For the plasma-assisted deposition process, a silver bar with $99.9 \%$ purity was used as target (cathode of the discharge). The Ag-bar was prepared by sanding one of its faces with 200 and 400 grit sandpaper, respectively, with subsequent ultrasound cleaning with isopropyl alcohol, 70\% ethanol, and distilled water, for 10 minutes in each solution.

\subsection{Plasma deposition and surface characterization}

Silver deposition on titanium samples was carried out by plasma sputtering. Titanium samples were placed on the anode of a diode glow discharge, face to face with the silver cathode. The cathode-anode distance was of $1 \mathrm{~cm}$. After evacuation of the discharge chamber to a residual pressure of about $30 \mathrm{mTorr}$, hydrogen at a flow rate of $50 \mathrm{sccm}$ (standard cubic centimeter per minute) was introduced into the chamber and the pressure was set to 0.5 Torr. Once the pressure stabilized, plasma was turned on and these conditions were held constant for 5 minutes. This step had the objective of cleaning the cathode (silver) and anode (sample) surface before starting the deposition process. Hydrogen was chosen since it produces a reactive plasma environment with very low sputtering rate. After cleaning $50 \mathrm{sccm}$ Argon was added, keeping the same pressure and the deposition process was started and lasted for $10 \mathrm{~min}$. The whole treatment was carried out using pulsed DC power supply set to a peak voltage of $700 \mathrm{~V}$ and pulse width of $10 \mu \mathrm{s}$ (for a pulse period of $240 \mu \mathrm{s}$ ). The plasma deposition process parameters were set to avoid silver deposition as a film over the Ti surface. After deposition all samples were again cleaned for three times in ultrasonic bath of isopropyl alcohol, 70\% ethanol, and distilled water, for $10 \mathrm{~min}$ in each solution.

The Ti/Ag surface morphology was analyzed by scanning electron microscope (SEM) and the surface chemical composition was measured by X-ray photoelectron spectroscopy (XPS) - Kratos Analytical XSAM HS Spectrometer- Mg K $\alpha$ (hv = $1253.6 \mathrm{eV})$, X-ray source: emission of $15 \mathrm{~mA}$ at a voltage of $15 \mathrm{kV}$. High-resolution spectra were obtained with an energy analyzer of $20 \mathrm{eV}$ resolutions for long analysis time (overnight). The binding energies were referred to the carbon 1s line, at $284.8 \mathrm{eV}$. A least-square routine was used for the peaks fitting.

By open circuit potential (OCP), the equilibrium potential of a metal immersed in an electrolytic solution is analyzed as a function of time until the steady state is reached. An electrochemical cell with two electrodes was used, being working electrodes: the sample and a saturated calomel reference electrode $\left(\mathrm{Hg}, \mathrm{Hg}_{2} \mathrm{Cl}_{2}\right.$, saturated $\left.\mathrm{KCl}\right)$. The electrolyte was an aqueous solution of artificial blood ${ }^{19}$.

\subsection{Antimicrobial assays}

The antimicrobial assays were conducted based on Kim et al. ${ }^{20}$ with some modifications. Cultures of Escherichia coli, and Staphylococcus aureus, Gram-negative and Gram-positive bacteria respectively were grown in Luria-Bertani (LB) broth (Tryptone $10 \mathrm{~g} / \mathrm{L}$, Yeast extract $5 \mathrm{~g} / \mathrm{L}, \mathrm{NaCl} 10 \mathrm{~g} / \mathrm{L} \mathrm{pH}$ 7.0) at $37{ }^{\circ} \mathrm{C}$ and $120 \mathrm{rpm}$ to reach $10^{7} \mathrm{CFU} / \mathrm{mL}$. The titanium control and cp-Ti/Ag samples were sterilized by UV light exposure for 1 hour. Next, the samples were placed in sterile Petri dishes with dividers containing autoclaved cotton soaked with sterilized water to prevent dehydration of the bacterial culture. A $50 \mu \mathrm{L}$ of bacterial culture was deposited on samples surface and incubated for 16 hours at $37^{\circ} \mathrm{C}$. After that, a $30 \mu \mathrm{L}$ of the inoculum was transferred to culture flasks containing $3 \mathrm{~mL}$ of LB broth at $37^{\circ} \mathrm{C}$ and $120 \mathrm{rpm}$. Cellular growth was evaluated by optical density measurements at $600 \mathrm{~nm}$ (O.D.600) after incubation of 2 hours, for $S$. aureus and after incubation of 6 hours for $E$. coli. Five repetitions of each tested condition were performed. The results were compared by t-test and differences were considered significant at $\mathrm{p}<0.05$ level (BioStat, AnalystSoft Inc.-Statistical Analysis Program v7).

\subsection{Cellular activity: biocompatibility assay}

BALB/3T3 clone 31 (ATCC® CCL-163 ${ }^{\mathrm{TM}}$ ) cell line (murine fibroblasts) were used to determine cell attachment and growth over cp-Ti control and Ti/Ag samples. Cell were grown in complete media - Dulbecco's modified Eagle's medium (DMEM) supplemented with $1 \mathrm{U} / \mathrm{mL}$ penicillin and $1 \mu \mathrm{g} / \mathrm{mL}$ streptomycin, and $10 \%$ fetal bovine serum (all from Gibco), and incubated at $37{ }^{\circ} \mathrm{C}$ in humidified atmosphere with $5 \% \mathrm{CO}_{2}$. For subculture and plating, the cells were washed with phosphate-buffered saline (PBS-Sigma-Aldrich), detached using $0.25 \%$ trypsin/EDTA (Gibco), and counted in Neubauer chamber. Cells were used for no more than 5 passages and confluence of no more than $80 \%$.

Titanium samples were autoclave sterilized for $1 \mathrm{~h}$ and placed on cell culture certified plastic Petri dishes. Sixty thousand cells in $200 \mu \mathrm{L}$ of complete media were plated in the top center of each sample, and incubated at $37{ }^{\circ} \mathrm{C}, 5 \% \mathrm{CO}_{2}$ for 30 minutes to allow cells attachment. Next, supernatant and plastic surface were observed under inverted light microscope to evaluate cells attachment to the metallic sample. The samples were totally covered by addition of complete media to the Petri dish. The absence of loose cells in the media was monitored over time. Plates were incubated for 7 days, under the same conditions described above. Culture media was replaced after 4 days of culture to maintain proper culture conditions.

Cells adhesion and growth on samples, as well as cells morphology, were observed by scanning electron microscopy (SEM). Routine protocol was used during SEM processing ${ }^{21}$. Briefly, after 7 days the cells were washed in sodium cacodilate buffer, $\mathrm{pH} 7.2$, fixed with $2.5 \%$ glutaraldehyde for $1 \mathrm{~h}$, and post-fixed in $1 \%$ osmium tetroxide for 30 min protected from light (all reagents from Electron Microscopy Sciences). Cells were next dehydrated in increasing ethanol (Merck) concentrations; critical point dried; sputtered with gold; and observed using a JEOL JSM-6360 LV SEM. Two samples from cp-Ti/Ag group and one sample from Ti-control group were observed, from 2 independent experiments.

\section{Results and Discussion}

\subsection{Ti-Ag surface characterization}

The titanium samples surfaces morphology, before and after Ag deposition, were analyzed by SEM as shown in Figure 2. Images obtained from grade 2 commercially pure titanium 

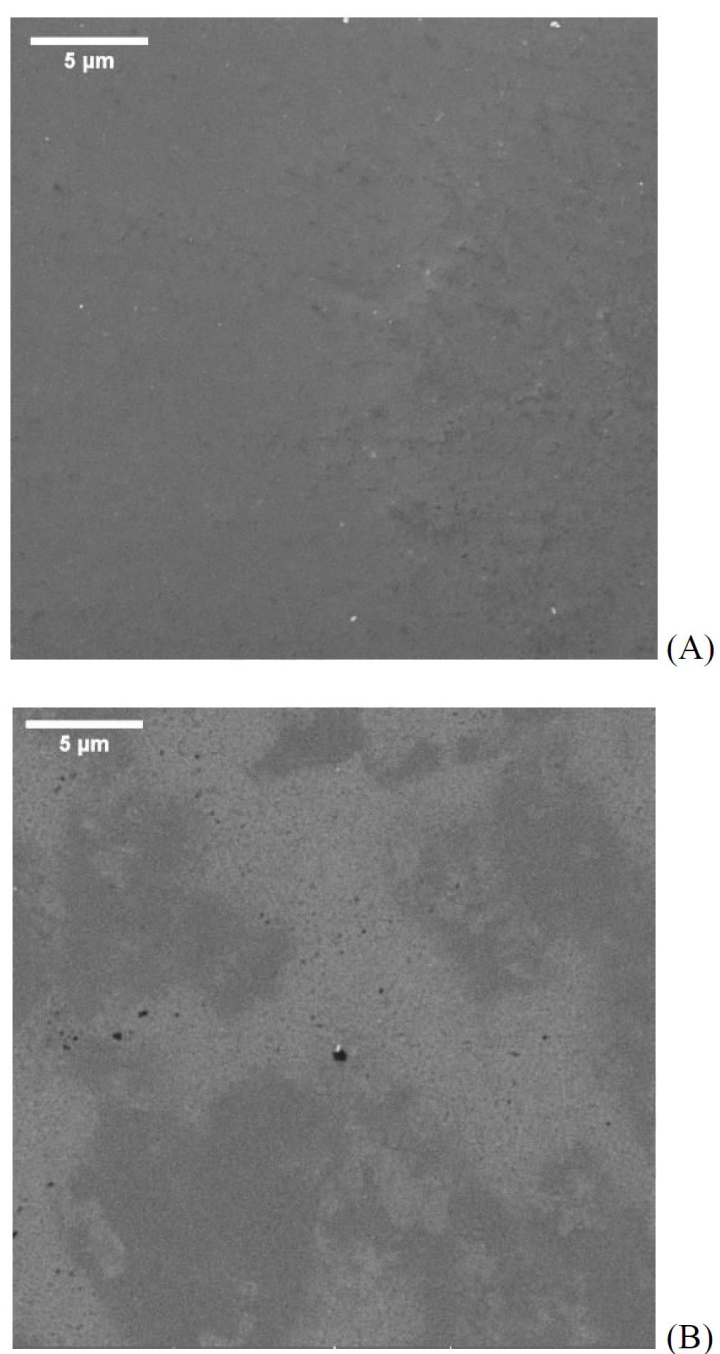

Figure 2. SEM images of (A) Ti control and of (B) Ti/Ag-10 min plasma deposition.

surface treated via plasma for 10 minutes (Figure 2B) lacked morphological indications of $\mathrm{Ag}$ presence when compared to the Ti-control (Figure 2A). Both treated and untreated surfaces presented an undefined morphology, characteristic of the presence of a titanium oxide thin film, which naturally grows on metal, over a mirror polished surface ${ }^{22}$. However, a slight contrast variation could be observed between different regions (Figure 2B), emphasizing that images were produced in the BSE mode, where lighter areas indicate regions formed by atoms of greater atomic number. Thus, it is possible that the lighter regions are richer in Ag. EDS elemental analysis were performed in the regions presenting different aspect, but no difference was detected. Thus, the XPS measurements were necessary.

Figure 3 shows the XPS spectra of each element detected on the studied surfaces enabling to measure the surface chemical composition (analysis depth: 0-10 nm) ${ }^{23}$, before and after the plasma treatment for Ag deposition.

The identification of titanium and oxygen on surfaces confirms the presence of $\mathrm{TiO}_{2}$ layer, inherent to this metal spontaneous oxidation process ${ }^{22}$. This result also indicates that $\mathrm{Ag}$ is deposited as discontinuous film, as required in this research. Figure $3 \mathrm{~A}$ presents a spectrum of the Ti-2p region, where the peak Ti $2 p$ is a doublet that consists in Ti $2 p_{1 / 2}$ and Ti $2 \mathrm{p}_{3 / 2}$ peaks. The doublet is determined by the peak at $458.0 \mathrm{eV}\left(\mathrm{Ti} 2 \mathrm{p}_{3 / 2}\right)$ characterizing the $\mathrm{TiO}_{2}$ presence. The small displacement observed in the doublet may be due to the presence of Ag in the Ti-Ag system but can also indicate the presence of $\mathrm{Ti}^{3+}$ due to oxygen vacancies, probably induced by the presence of hydrogen during the $\mathrm{Ag}$ deposition process $^{24}$. Figure $3 \mathrm{C}$ shows the spectrum of the $\mathrm{Ag} 3 \mathrm{~d}_{5 / 2}$ region, where the peak $\mathrm{Ag} 3 \mathrm{~d}$ is a doublet determined by the peak at $367.5 \mathrm{eV}^{10}$, it indicates the presence of $\mathrm{Ag}-\mathrm{O}$ bonds, probably formed after deposition due the exposition to the ambient atmosphere. And Figure 3B presents a spectrum of the $\mathrm{O} 1 \mathrm{~s}$ region, where $\mathrm{O} 1 \mathrm{~s}$ is a singlet determined by the peak $529.2 \mathrm{eV}$. The Ti-OH chemical bond could be attributed to the shoulder presence at $532 \mathrm{eV}$ peak $^{17,23}$.

By XPS quantitative analysis $1.3 \mathrm{at} \% \mathrm{Ag}$ was measured on $\mathrm{Ti} / \mathrm{Ag}$ surface. It should be noted that on the Ti-control sample surface, the Ag percentage was equal to zero.

The dissolution of deposited Ag can affect its toxicity and persistence in the environment. Thus, it appears that this bactericidal inorganic element remained stable on the surface after the ultrasonic cleaning procedure applied. This fact corroborates with the open circuit potential (OCP) analysis in artificial blood medium, as the chemical stability of deposited Ag on Ti was demonstrated. The spontaneous potential was analyzed in open circuit conditions (Table 1). A more noble (less negative) stationary potential of Ag containing surface was observed in relation to the control indicating that $\mathrm{Ti} / \mathrm{Ag}$ system treated by plasma is thermodynamically stable and dissolution resistant in artificial blood, and should be suitable for implant applications. Several studies described the dissolution of Ag species in body fluids with silver chloride precipitation, besides the dissolution tendency in relation to the Ag particles size $\mathrm{e}^{25,26}$. In summary, the $\mathrm{Ag}$ element remained stable on the Ti surface in this present condition.

\subsection{Bactericide action of cp-Ti/Ag surface}

Taking into account the mean value of O.D.600, the presence of silver inhibited bacterial growth for both $E$. coli and $S$. aureus (Table 2). Nevertheless, the statistical significance of this effect was stated to Gram-negative $E$. coli. The main toxicological effect induced by antimicrobial surfaces in bacteria occurs by direct contact with the cell surface ${ }^{6}$. Therefore it is important to report some differences between the cell wall of Gram-positive and Gram-negative bacteria. It is known that Gram-positive bacteria like $S$. aureus present a thicker cellular wall $(30 \mathrm{~nm})$ whereas from Gram-negative bacteria it is around $3-4 \mathrm{~nm}^{27}$. Despite the thickness, both Gram-positive and Gram-negative bacteria have a negatively charged surface but Gram-negative bacteria have a phospholipid outer membrane with partially phosphorylated lipopolysaccharides (LPS) that increase their negative surface charge, attracting positively charged ions due to electrostatic interactions ${ }^{6}$. Kim et al. ${ }^{28}$ observed similar results with E. coli and $S$. aureus, where silver deposits were spread in a concentration of 0.2 to $33 \mathrm{nM}\left(0.2 \times 10^{-6}\right.$ to $\left.33 \times 10^{-6} \mathrm{mM} / \mathrm{L}\right)$ on the cultures surface. The growth-inhibitory effect was evident for $E$. coli but less effective for $S$. aureus. Other 


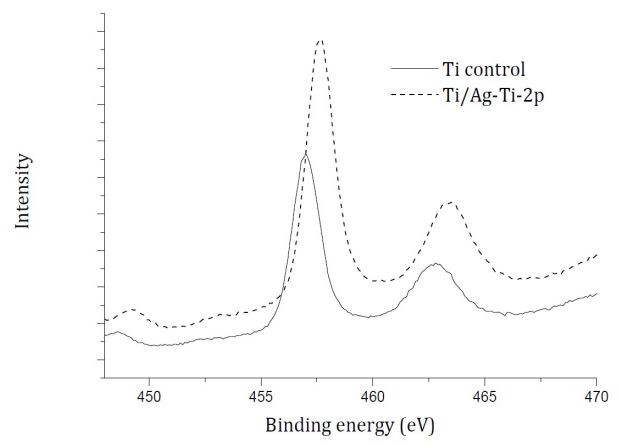

(A)
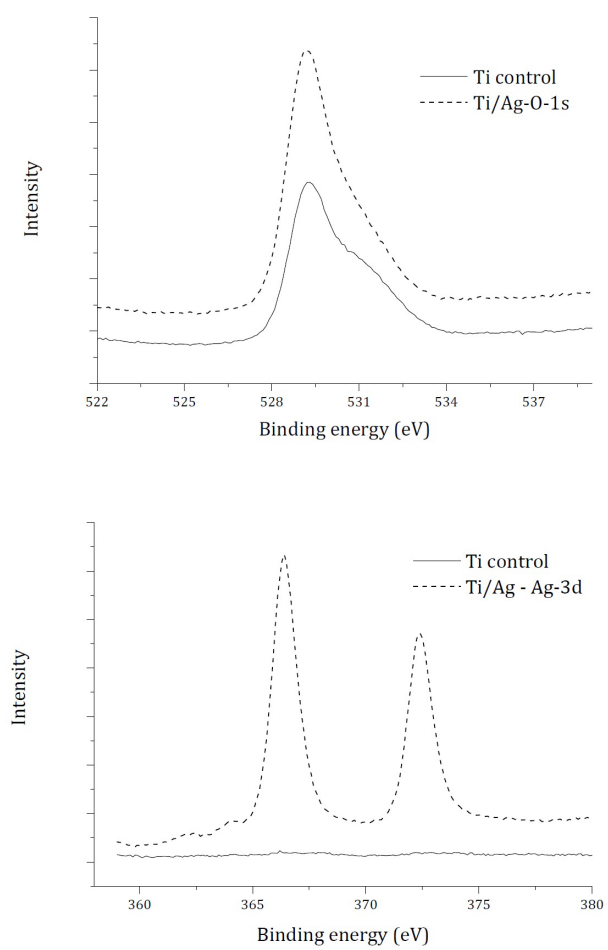

Figure 3. XPS spectra of major elements present on the surfaces of control samples and Ti/Ag plasma deposited samples (10 minutes), (A) Titanium, (B) Oxygen and (C) Silver.

Table 1. Open circuit potential for Ti-control and Ti/Ag in artificial blood.

\begin{tabular}{ccc}
\hline Immersion time & OCP Ti-control & $\begin{array}{c}\text { OCP Ti/Ag-10 min } \\
\text { plasma }\end{array}$ \\
\hline $120 \mathrm{~min}$ & $-65 \mathrm{mV}$ & $-44 \mathrm{mV}$ \\
\hline
\end{tabular}

Table 2. Optical density for growth analysis of E. coli and S. aureus bacteria on Ti and Ti-Ag samples, after $16 \mathrm{~h}$ time incubation at $37^{\circ} \mathrm{C}$.

\begin{tabular}{lcccc}
\hline Bacteria & Treatment & Mean & SD & P value \\
\hline \multirow{2}{*}{ E. coli } & Ti control & 1.8837 & 0.0601 & \multirow{2}{*}{$0.0092^{*}$} \\
\cline { 2 - 4 } & $\mathrm{Ti} / \mathrm{Ag}$ & 1.4600 & 0.1401 & \\
\hline \multirow{2}{*}{ S. aureus } & $\mathrm{Ti}$ control & 0.3251 & 0.1110 & \multirow{2}{*}{0.1028} \\
\cline { 2 - 4 } & $\mathrm{Ti} / \mathrm{Ag}$ & 0.1996 & 0.2547 &
\end{tabular}

Notes: $\mathrm{SD}=$ standard deviation. P value $=$ level of significance. ${ }^{*}=$ statistically significant. authors reported that the number of colony-forming units of S. aureus decreased significantly with increased Ag content ${ }^{29,30}$. It is worth mentioning that here the titanium surface was prepared with very low Ag concentrations which indicate this inorganic element performance as an antibacterial agent. However, in order to achieve an efficient result, it is expected a specific action, meaning that a balance between Ag antibacterial activity and nontoxic effects to the host ${ }^{20}$ could be found. Therefore, the next step was to investigate it on mammalian cells.

\subsection{In vitro fibroblasts culture: surface biocompatibility study}

Studies with high Ag concentrations are commonly presented in the literature, as example, the well-defined titanium nanotubes arrays containing $\mathrm{Ag}$ concentrations up to 15 at $\%{ }^{31-33}$. These higher Ag concentrations could confer an important limitation because it leads to bacteria growth inhibition but can produce cytotoxicity ${ }^{34}$. Commonly to access biomaterials biocompatibility cells attachment and growth are evaluated. ISO 10993-5:2009- Biological evaluation of medical devices - Part 5: Tests for in vitro cytotoxicity $^{35}$ - standardize the use of murine fibroblasts as a mode to determine in vitro cell viability and therefore we have used this cell line to determine it. Moreover, biomaterials integration is known to be dependent on this cell type ${ }^{36}$, and cell adhesion to the material is directly correlated to biocompatibility ${ }^{37}$. Therefore, we have investigated if the proposed material is biocompatible (based on cell attachment and growth) even in the presence of a bactericidal agent.

Here, after 30 minutes of cells incubation over Ti-control and $\mathrm{Ti} / \mathrm{Ag}$ samples, neither floating cells in the media nor adhered cells in the plastic were observed (data not shown). These facts indicated cell attachment on the samples surface. These parameters were monitored every day, up to 7 days, and no cells detachment was observed. In order to confirm cell adhesion, after 7 days in cell culture conditions samples were processed and observed by SEM. A fibroblast layer covering both samples was found (Figure 4A and Figure 4B), demonstrating that cells were able not only to adhere but also to proliferate over it. Typical elongated spindle-shaped fibroblast morphology was observed on the Ti-control group (Figure 4A), corroborating titanium biocompatibility ${ }^{8}$, as well on the Ti/Ag group (Figure 4B) indicating non-significant cytotoxicity to this cell type. Interestingly, as described above, bactericidal effect of Ti/Ag was found. These results indicate that the low silver concentration deposited on the samples used in this study can specifically impair bacterial growth without interfering with normal fibroblasts growth.

Biocompatibility, demonstrated by cell adhesion and proliferation to titanium, the gold standard biomaterial, is essential to implants success. Silver integration to those implants can be beneficial if its toxic effects are specific and directed at the pathogenic agents, but not to the patients cells. Finding this balance is often difficult, but in this study we were able to describe an efficient method to deposit silver on titanium surfaces, and to demonstrate that the obtained product is able to impair bacterial growth without interfering with the material biocompatibility. Taken together these findings indicate that this treatment could be potentially used as safe implants with bactericidal action. 


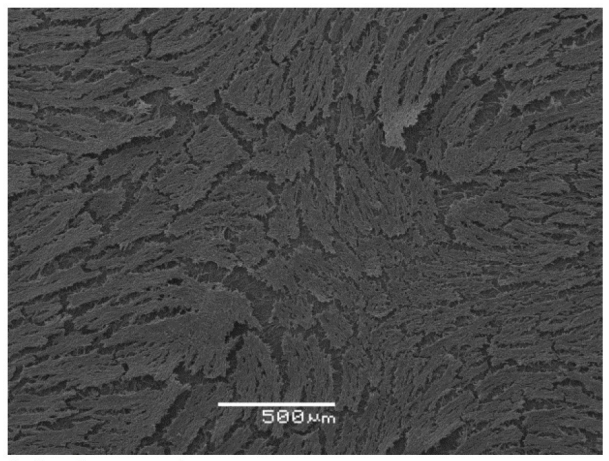

(A) Ti control

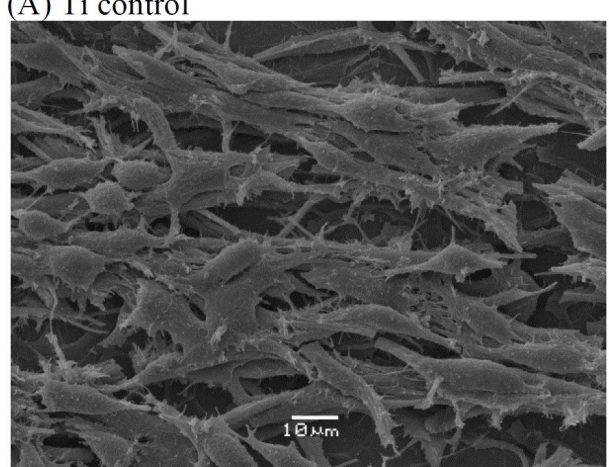

(A') Ti control

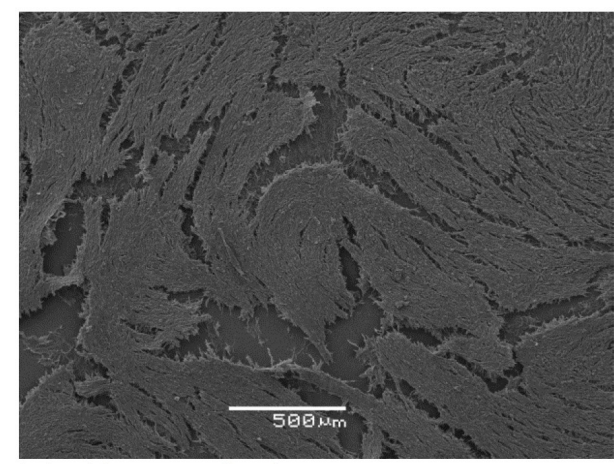

(B) Ti/Ag-10 min plasma

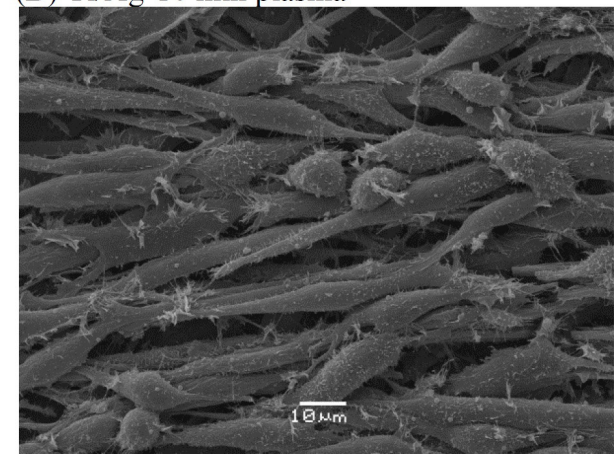

(B') Ti/Ag-10 min plasma

Figure 4. Determination of samples biocompatibility. SEM images of murine fibroblasts adhered to (A and A') Ti-control and (B and B') Ti-Ag samples after 7 days grown in routine cell culture conditions.

\section{Conclusions}

Stable Ag deposits on a cp-Ti substrate were obtained by a fast plasma-assisted sputtering deposition technique (10 minutes). As this technique allows the fine parameters control, a precise amount of deposited material was obtained, essential to achieve the required surface characteristics. Surfaces with $1.3 \mathrm{at} \% \mathrm{Ag}$, measured by XPS, were obtained. The analysis of bacterial growth by the optical density of E. coli and S. aureus strains in Ti/Ag indicated a promising bactericidal action. In addition, biocompatibility tests with fibroblasts showed elongated cell morphology on the surface of the $\mathrm{Ti} / \mathrm{Ag}$ system, indicating absence of toxicity.

\section{Acknowledgments}

The authors acknowledge the financial support from CNPq (grant C.E.B. Marino-303126/2019-1; V. Kava 312516/2019-3; R.P. Cardoso 313606/2018-8), CAPES (Finance code 001) and the Electron Microscopy Center of UFPR (CME-UFPR). E.R. Camargo \& K.Z. Hamdar are grateful to CNPq for the scholarship. M.L.F. Santos \& G. Burgel are grateful to CAPES for the scholarship. The authors are grateful to LabCet (ICC/Fiocruz) for kindly providing the BALB/3T3 cells.

\section{References}

1. Zhao L, Wang H, Huo K, Cui L, Zhang W, Ni H, et al. Antibacterial nano-structured titania coating incorporated with silver nanoparticles. Biomaterials. 2011;32(24):5706-16. http:// dx.doi.org/10.1016/j.biomaterials.2011.04.040.
2. Ferraris S, Spriano S. Antibacterial titanium surfaces for medical implants. Mater Sci Eng C. 2016;61:965-78. http:// dx.doi.org/10.1016/j.msec.2015.12.062.

3. Reyes-Vidal Y, Suarez-Rojas R, Ruiz C, Torres J, Țălu Ş, Méndez A, et al. Electrodeposition, characterization, and antibacterial activity of zinc/silver particle composite coatings. Appl Surf Sci [serial on the Internet]. 2015 [cited 2020 Dec 13];342:3441. Available from: https://linkinghub.elsevier.com/retrieve/ pii/S0169433215006042

4. Saleem M, Deters B, de la Bastide A, Korzen M. Antibiotics overuse and bacterial resistance. Ann Microbiol Res. 2018;2(1):45-50.

5. Rai M, Yadav A, Gade A. Silver nanoparticles as a new generation of antimicrobials. Biotechnol Adv. 2009;27(1):76-83. http:// dx.doi.org/10.1016/j.biotechadv.2008.09.002.

6. Sánchez-López E, Gomes D, Esteruelas G, Bonilla L, LopezMachado AL, Galindo R, et al. Metal-based nanoparticles as antimicrobial agents: an overview. Nanomaterials (Basel) [serial on the Internet]. 2020 [cited 2020 Dec 13];10(2):292. Available from: https://www.mdpi.com/2079-4991/10/2/292

7. Durán N, Durán M, de Jesus MB, Seabra AB, Fávaro WJ, Nakazato G. Silver nanoparticles: a new view on mechanistic aspects on antimicrobial activity. Nanomedicine Nanotechnology. Biol Med (Aligarh). 2016;12(3):789-99. http://dx.doi.org/10.1016/j. nano.2015.11.016.

8. Kheur S, Singh N, Bodas D, Rauch J-Y, Jambhekar S, Kheur $\mathrm{M}$, et al. Nanoscale silver depositions inhibit microbial colonization and improve biocompatibility of titanium abutments. Colloids Surf B Biointerfaces. 2017;159:151-8. http://dx.doi. org/10.1016/j.colsurfb.2017.07.079.

9. Ovington LG. The truth about silver. Ostomy Wound Manage. 2004;50(9A Suppl):1S-10S. PMID: 15499162.

10. Bai L, Hang R, Gao A, Zhang X, Huang X, Wang Y, et al. Nanostructured titanium-silver coatings with good antibacterial activity and cytocompatibility fabricated by one-step magnetron 
sputtering. Appl Surf Sci. 2015;355:32-44. http://dx.doi. org/10.1016/j.apsusc.2015.07.064.

11. Feng QL, Wu J, Chen GQ, Cui FZ, Kim TN, Kim JO. A mechanistic study of the antibacterial effect of silver ions onEscherichia coli andStaphylococcus aureus. J Biomed Mater Res [serial on the Internet]. 2000 [cited 2020 Dec 13];52(4):662-8. Available from: https://pubmed.ncbi.nlm.nih.gov/11033548/

12. Ahmed MH, Keyes TE, Byrne JA. The photocatalytic inactivation effect of Ag-TiO2 on $\beta$-amyloid peptide (1-42). J Photochem Photobiol Chem. 2013;254:1-11. http://dx.doi.org/10.1016/j. jphotochem.2012.12.019.

13. Vazquez-Muñoz R, Borrego B, Juárez-Moreno K, García-García M, Mota Morales JD, Bogdanchikova N, et al. Toxicity of silver nanoparticles in biological systems: does the complexity of biological systems matter? Toxicol Lett. 2017;276:11-20. http://dx.doi.org/10.1016/j.toxlet.2017.05.007.

14. Heidenau F, Mittelmeier W, Detsch R, Haenle M, Stenzel F, Ziegler $\mathrm{G}$, et al. A novel antibacterial titania coating: metal ion toxicity and in vitro surface colonization. J Mater Sci Mater Med [serial on the Internet]. 2005 [cited 2020 Dec 13];16(10):883-8. Available from: http://link.springer.com/10.1007/s10856-005-4422-3

15. Trujillo NA, Oldinski RA, Ma H, Bryers JD, Williams JD, Popat KC. Antibacterial effects of silver-doped hydroxyapatite thin films sputter deposited on titanium. Mater Sci Eng C. 2012;32(8):2135-44. http://dx.doi.org/10.1016/j.msec.2012.05.012.

16. Necula BS, van Leeuwen JPTM, Fratila-Apachitei LE, Zaat SAJ, Apachitei I, Duszczyk J. In vitro cytotoxicity evaluation of porous $\mathrm{TiO} 2-\mathrm{Ag}$ antibacterial coatings for human fetal osteoblasts. Acta Biomater. 2012;8(11):4191-7. http://dx.doi. org/10.1016/j.actbio.2012.07.005.

17. Thukkaram M, Cools P, Nikiforov A, Rigole P, Coenye T, Van Der Voort P, et al. Antibacterial activity of a porous silver doped $\mathrm{TiO}_{2}$ coating on titanium substrates synthesized by plasma electrolytic oxidation. Appl Surf Sci. 2020;500:144235. http:// dx.doi.org/10.1016/j.apsusc.2019.144235.

18. Zhang X, Wu H, Geng Z, Huang X, Hang R, Ma Y, et al. Microstructure and cytotoxicity evaluation of duplex-treated silver-containing antibacterial TiO2 coatings. Mater Sci Eng C. 2014;45:402-10. http://dx.doi.org/10.1016/j.msec.2014.07.002.

19. ASTM International. ASTM F2129.19a - Standard Test Method for Conducting Cyclic Potentiodynamic Polarization Measurements to Determine the Corrosion Susceptibility of Small Implant Devices [Internet]. West Conshohocken, PA: ASTM International. [cited 2020 Dec 13]. Available from: http://www.astm.org/cgi-bin/resolver.cgi?F2129-19a

20. Kim S, Park C, Cheon K-H, Jung H-D, Song J, Kim H-E, et al. Antibacterial and bioactive properties of stabilized silver on titanium with a nanostructured surface for dental applications. Appl Surf Sci. 2018;451:232-40. http://dx.doi.org/10.1016/j. apsusc.2018.04.270.

21. Fischer ER, Hansen BT, Nair V, Hoyt FH, Dorward DW. Scanning electron microscopy. Curr Protoc Microbiol [serial on the Internet]. 2012 [cited 2020 Dec 13];25(1):2B.2.12B.2.47. Available from: https://onlinelibrary.wiley.com/ doi/10.1002/9780471729259.mc02b02s25

22. Marino CEB, Nascente PAP, Biaggio SR, Rocha-Filho RC, Bocchi N. XPS characterization of anodic titanium oxide films grown in phosphate buffer solutions. Thin Solid Films [serial on the Internet]. 2004 [cited 2020 Dec 13];468(1-2):109-12. Available from: https://linkinghub.elsevier.com/retrieve/pii/ S0040609004005486

23. Sham TK, Lazarus MS. X-ray photoelectron spectroscopy (XPS) studies of clean and hydrated $\mathrm{TiO}_{2}$ (rutile) surfaces. Chem Phys Lett [serial on the Internet]. 1979 [cited 2020 Dec 13];68(2-3):426-32. Available from: https://linkinghub.elsevier. com/retrieve/pii/0009261479872310
24. Anaam SAA, Saim H, Sahdan MZ, Al-Gheethi A. Defective TiO2 with intrinsic point defects for photocatalytic hydrogen production: a review. Int J Nanoelectron Mater. 2019;12(4):495-516.

25. Loza K, Diendorf J, Sengstock C, Ruiz-Gonzalez L, GonzalezCalbet JM, Vallet-Regi M, et al. The dissolution and biological effects of silver nanoparticles in biological media. J Mater Chem B Mater Biol Med [serial on the Internet]. 2014 [cited 2020 Dec 13];2(12):1634. Available from: http://xlink.rsc. org/?DOI $=\mathrm{c} 3 \mathrm{tb} 21569 \mathrm{e}$

26. Ma R, Levard C, Marinakos SM, Cheng Y, Liu J, Michel FM, et al. Size-controlled dissolution of organic-coated silver nanoparticles. Environ Sci Technol [serial on the Internet]. 2012 [cited 2020 Dec 13];46(2):752-9. Available from: https://pubs. acs.org/doi/10.1021/es201686j

27. Qing Y, Cheng L, Li R, Liu G, Zhang Y, Tang X, et al. Potential antibacterial mechanism of silver nanoparticles and the optimization of orthopedic implants by advanced modification technologies. Int J Nanomedicine [serial on the Internet]. 2018 [cited 2020 Dec 13];13:3311-27. Available from: https://www. dovepress.com/potential-antibacterial-mechanism-of-silvernanoparticles-and-the-opti-peer-reviewed-article-IJN

28. Kim JS, Kuk E, Yu KN, Kim J-H, Park SJ, Lee HJ, et al. Antimicrobial effects of silver nanoparticles. Nanomedicine Nanotechnology. Biol Med [serial on the Internet]. 2007 [cited 2020 Dec 13];3(1):95-101. Available from: https://linkinghub. elsevier.com/retrieve/pii/S1549963406003467

29. Kelly PJ, Li H, Whitehead KA, Verran J, Arnell RD, Iordanova I. A study of the antimicrobial and tribological properties of TiN/Ag nanocomposite coatings. Surf Coat Tech. 2009;204(6-7):113740. http://dx.doi.org/10.1016/j.surfcoat.2009.05.012.

30. Sharma N, Kumar J, Thakur S, Sharma S, Shrivastava V. Antibacterial study of silver doped zinc oxide nanoparticles against Staphylococcus aureus and Bacillus subtilis. Drug Invent Today. 2013;5(1):50-4. http://dx.doi.org/10.1016/j. dit.2013.03.007.

31. Gao A, Hang R, Huang X, Zhao L, Zhang X, Wang L, et al. The effects of titania nanotubes with embedded silver oxide nanoparticles on bacteria and osteoblasts. Biomaterials. 2014;35(13):4223-35. http://dx.doi.org/10.1016/j.biomaterials.2014.01.058.

32. Arash V, Keikhaee F, Rabiee SM, Rajabnia R, Khafri S, Tavanafar S. Evaluation of antibacterial effects of silver-coated stainless steel orthodontic brackets. J Dent (Tehran) [serial on the Internet]. 2016 [cited 2020 Dec 13];13(1):49-54. Available from: http:/ www.ncbi.nlm.nih.gov/pubmed/27536328\%0Ahttp://www. pubmedcentral.nih.gov/articlerender.fcgi?artid=PMC4983565

33. Liao C, Li Y, Tjong S. Bactericidal and cytotoxic properties of silver nanoparticles. Int J Mol Sci [serial on the Internet]. 2019 [cited 2020 Dec 13];20(2):449. Available from: http:// www.mdpi.com/1422-0067/20/2/449

34. Xinping L, Shengli L, Miaotao Z, Wenlong Z, Chuanghong L. Evaluations of antibacterial activity and cytotoxicity on Ag nanoparticles. Rare Met Mater Eng. 2011;40(2):209-14. http:// dx.doi.org/10.1016/S1875-5372(11)60017-9.

35. International Organization for Standardization. ISO $10993-$ 5:2009(E) - Biological evaluation of medical devices - Part 5: Tests for in vitro cytotoxicity [Internet]. Genebra: ISO; 2009 [cited 2020 Dec 13]. Available from: https://www.iso. org/standard/36406.html

36. Hannan RT, Peirce SM, Barker TH. Fibroblasts: diverse cells critical to biomaterials integration. ACS Biomater Sci Eng. 2018;4(4):1223-32. https://doi.org/10.1021/acsbiomaterials.7b00244.

37. Lotfi M, Nejib M, Naceur M. Cell adhesion to biomaterials: concept of biocompatibility. In: Pignatello R, editor. Advances in biomaterials science and biomedical applications [Internet]. London: InTech; 2013. p. 137-44 [cited 2020 Dec 13]. Available from: http://www.intechopen.com/books/advances-inbiomaterials-science-and-biomedical-applications/cell-adhesionto-biomaterials-concept-of-biocompatibility 